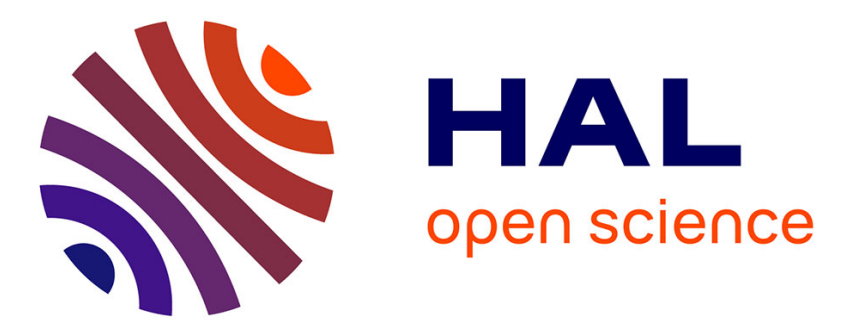

\title{
Hydrogen Production from raw bioethanol steam reforming: optimization of catalyst composition with improved stability against various impurities
}

Anthony Le Valant, Fabien Can, Nicolas Bion, Daniel Duprez, Florence Epron

\section{- To cite this version:}

Anthony Le Valant, Fabien Can, Nicolas Bion, Daniel Duprez, Florence Epron. Hydrogen Production from raw bioethanol steam reforming: optimization of catalyst composition with improved stability against various impurities. International Journal of Hydrogen Energy, 2010, 35 (10), pp.5015-5020. 10.1016/j.ijhydene.2009.09.008 * hal-02109875

\section{HAL Id: hal-02109875 \\ https://hal.science/hal-02109875}

Submitted on 20 Aug 2021

HAL is a multi-disciplinary open access archive for the deposit and dissemination of scientific research documents, whether they are published or not. The documents may come from teaching and research institutions in France or abroad, or from public or private research centers.
L'archive ouverte pluridisciplinaire HAL, est destinée au dépôt et à la diffusion de documents scientifiques de niveau recherche, publiés ou non, émanant des établissements d'enseignement et de recherche français ou étrangers, des laboratoires publics ou privés. 
HYDROGEN PRODUCTION FROM RAW BIOETHANOL STEAM REFORMING: OPTIMIZATION OF CATALYST COMPOSITION WITH IMPROVED STABILITY AGAINST VARIOUS IMPURITIES

Anthony Le Valant, Fabien Can, Nicolas Bion, Daniel Duprez and Florence Epron Laboratoire de Catalyse en Chimie organique, UMR6503 CNRS, Université de Poitiers 40 avenue du recteur Pineau, 86022 Poitiers Cedex (France)

*florence.epron.cognet@univ-poitiers.fr 


\section{ABSTRACT}

The use of raw bioethanol is of major importance for a cost effective industrial application. Raw bioethanol contains higher alcohols as the main impurities and also aldehydes, amines, acids and esters. The effect of these impurities on the catalytic performances for ethanol steam reforming (ESR) has been studied, using a reference catalyst, $\mathrm{Rh} / \mathrm{MgAl}_{2} \mathrm{O}_{4}$. It was shown that the aldehyde, the amine and methanol has no negative effect on the catalytic performances, contrary to the ester, acid and higher alcohols. The deactivation is mainly explained by coke formation favored by the presence of these impurities in the feed. In order to improve the stability of the catalyst and its performances in the presence of these deactivating impurities, the catalyst formulation, i.e. the composition of the support and of the metallic phase, was modified. The addition of rare earth elements instead of magnesium to the alumina support leads to a decrease of the strong and medium acid sites and to an increase of the basicity. On these modified supports, the dehydration reaction, leading to olefins, which are coke precursors, is disfavored, the ethanol conversion and the hydrogen yield are increased. The best catalytic performances were obtained with $\mathrm{Rh} / \mathrm{Y}-\mathrm{Al}_{2} \mathrm{O}_{3}$. Then, the metallic phase was also modified by adding a second metal (Ni, Pt or $\mathrm{Pd})$. The $\mathrm{Rh}-\mathrm{Ni} / \mathrm{Y}-\mathrm{Al}_{2} \mathrm{O}_{3}$ catalyst leads to the highest hydrogen yield. This catalyst, tested in the presence of raw bioethanol during $24 \mathrm{~h}$ was very stable compared to the reference catalyst $\mathrm{Rh} / \mathrm{MgAl}_{2} \mathrm{O}_{4}$, which was strongly deactivated after $2 \mathrm{~h}$ of time-on -stream.

\section{Key words: ethanol steam reforming, crude bioethanol, rhodium catalysts}




\section{INTRODUCTION}

With the aim of reducing the global emissions of greenhouse gases, hydrogen should be produced from renewable resources such as bioethanol, which can be obtained by fermentation of several biomass sources. The catalytic steam reforming of bioethanol constitutes thus a promising route to hydrogen production (1-12) since the $\mathrm{CO}_{2}$ produced during this process is consumed by the plant during its growth. The main products of ethanol steam reforming are $\mathrm{H}_{2}, \mathrm{CO}_{2}, \mathrm{CO}$ (Eq. 1 and 2) whereas the hydrogenation of ethanol is responsible for the formation of methane (Eq. 3).

$$
\begin{array}{lc}
\mathrm{C}_{2} \mathrm{H}_{5} \mathrm{OH}(\mathrm{g})+3 \mathrm{H}_{2} \mathrm{O}_{(\mathrm{g})} \rightarrow 2 \mathrm{CO}_{2(\mathrm{~g})}+6 \mathrm{H}_{2(\mathrm{~g})} & \Delta \mathrm{H}^{0}{ }_{298 \mathrm{~K}}=173.3 \mathrm{~kJ} \mathrm{~mol}^{-1} \\
\mathrm{C}_{2} \mathrm{H}_{5} \mathrm{OH}_{(\mathrm{g})}+\mathrm{H}_{2} \mathrm{O}_{(\mathrm{g})} \rightarrow 2 \mathrm{CO}_{(\mathrm{g})}+4 \mathrm{H}_{2(\mathrm{~g})} & \Delta \mathrm{H}^{0}{ }_{298 \mathrm{~K}}=255.0 \mathrm{~kJ} \mathrm{~mol}^{-1} \\
\mathrm{C}_{2} \mathrm{H}_{5} \mathrm{OH}_{(\mathrm{g})}+2 \mathrm{H}_{2(\mathrm{~g})} \rightarrow 2 \mathrm{CH}_{4(\mathrm{~g})}+\mathrm{H}_{2} \mathrm{O}_{(\mathrm{g})} & \Delta \mathrm{H}^{0}{ }_{298 \mathrm{~K}}=-156.7 \mathrm{~kJ} \mathrm{~mol}^{-1}
\end{array}
$$

Methane and carbon monoxide produced during the reaction can be easily removed from the gas flow. The major intermediate products are acetaldehyde and ethylene, resulting, respectively from ethanol dehydrogenation (Eq. 4), and ethanol dehydration, (Eq. 5).

$$
\begin{aligned}
& \mathrm{C}_{2} \mathrm{H}_{5} \mathrm{OH}_{(\mathrm{g})} \rightarrow \mathrm{CH}_{3} \mathrm{CHO}_{(\mathrm{g})}+\mathrm{H}_{2(\mathrm{~g})} \quad \Delta \mathrm{H}^{0}{ }_{298 \mathrm{~K}}=68.0 \mathrm{~kJ} \mathrm{~mol}^{-1} \\
& \mathrm{C}_{2} \mathrm{H}_{5} \mathrm{OH}_{(\mathrm{g})} \rightarrow \mathrm{C}_{2} \mathrm{H}_{4(\mathrm{~g})}+\mathrm{H}_{2} \mathrm{O}_{(\mathrm{g})} \quad \Delta \mathrm{H}^{0}{ }_{298 \mathrm{~K}}=45 \mathrm{~kJ} \mathrm{~mol}^{-1}
\end{aligned}
$$

The thermal decomposition of ethanol may also yield methane, $\mathrm{CO}$ and $\mathrm{H}_{2}$ (Eq. 6).

$\mathrm{C}_{2} \mathrm{H}_{5} \mathrm{OH}_{(\mathrm{g})} \rightarrow \mathrm{CO}_{(\mathrm{g})}+\mathrm{CH}_{4(\mathrm{~g})}+\mathrm{H}_{2(\mathrm{~g})} \quad \Delta \mathrm{H}^{0}{ }_{298 \mathrm{~K}}=50 \mathrm{~kJ} \mathrm{~mol}^{-1}$

The ethanol dehydration reaction occurs mainly on the acid sites of the support. The formation of ethylene favors the catalyst deactivation, ethylene being a coke precursor (13). The ethanol dehydrogenation reaction depends not only on the basicity of the supports but also on the activity of supported metals in dehydrogenation. 
Among noble metals, rhodium is the most active for ethanol steam reforming (2-5). As far as the support is concerned, it may favor water splitting into $\mathrm{OH}$ groups and promote the migration of these reactive species toward the metal particles, it contributes to the formation of intermediate acetaldehyde and/or ethylene and it may affect the stability of the metal particles at high temperature under steam. Auprêtre et al (8) have optimized the catalyst formulation in order to obtain active and stable catalyst for $\mathrm{H}_{2}$ production by ethanol steam reforming at $700^{\circ} \mathrm{C}$ and $10 \mathrm{bar}$ and the best results were obtained with the $\mathrm{Rh} / \mathrm{MgAl}_{2} \mathrm{O}_{4}$ catalyst supported on alumina beads.

Except some papers $(14,15)$, studies reported in the literature on bioethanol steam reforming generally deal with the use of a mixture of water and pure ethanol. However, the use of a raw bioethanol feed, limiting the purification steps, is of major importance for a cost effective industrial application. But the presence of impurities in the feed could induce the deactivation of the catalyst.

The aim of this paper is (i) to show the effect of impurities present in raw bioethanol, such as esters, aldehydes, amine, acetic acid, methanol, linear or branched alcohols, on the stability of a $\mathrm{Rh} / \mathrm{MgAl}_{2} \mathrm{O}_{4}$ catalyst during bioethanol steam reforming for hydrogen production and (ii) to improve the stability of the catalyst against deactivating impurities by modifying the support and metallic phase composition.

\section{EXPERIMENTAL}

For the reference catalyst $\mathrm{Rh} / \mathrm{MgAl}_{2} \mathrm{O}_{4}$, the support was prepared by impregnation of magnesium acetate onto $\gamma-\mathrm{Al}_{2} \mathrm{O}_{3}$ beads (diameter 1-2 mm, AXENS). The amount of salt was adjusted to obtain $5 \mathrm{wt} . \% \mathrm{Mg}$ in the support. The spinel structure was obtained by calcination under air at $1000^{\circ} \mathrm{C}$ for 15h (5). The $1 \mathrm{wt} . \% \mathrm{Rh} / \mathrm{MgAl}_{2} \mathrm{O}_{4}$ catalyst was prepared by impregnation of a rhodium chloride precursor salt on the support, followed by calcination under air at $700^{\circ} \mathrm{C}$ for $4 \mathrm{~h}$.

For the modified support, the alumina beads were modified by wet impregnation using an appropriate amount of nitrate precursors of rare earth elements $\left(\mathrm{Sc}\left(\mathrm{NO}_{3}\right)_{3}, \mathrm{Y}\left(\mathrm{NO}_{3}\right)_{3}, \mathrm{La}\left(\mathrm{NO}_{3}\right)_{3}\right.$, 
$\mathrm{Er}\left(\mathrm{NO}_{3}\right)_{3}$ and $\left.\mathrm{Gd}\left(\mathrm{NO}_{3}\right)_{3}\right)$, in order to obtain $10 \mathrm{wt} . \%$ of rare earth element on the support. After impregnation and drying, supports were calcined at $900^{\circ} \mathrm{C}$ for $15 \mathrm{~h}$ at $5^{\circ} \mathrm{C} \mathrm{min}^{-1}$. The nonimpregnated alumina support was submitted to the same calcination treatment. The supports are referred as $\mathrm{Al}_{2} \mathrm{O}_{3}, \mathrm{Sc}-\mathrm{Al}_{2} \mathrm{O}_{3}, \mathrm{Y}-\mathrm{Al}_{2} \mathrm{O}_{3}, \mathrm{La}-\mathrm{Al}_{2} \mathrm{O}_{3}, \mathrm{Er}-\mathrm{Al}_{2} \mathrm{O}_{3}$ and Gd- $\mathrm{Al}_{2} \mathrm{O}_{3}$. Bimetallic Rh-Ni, RhPt and Rh-Pd catalysts were obtained by coimpregnation of the precursor salt (1wt.\% of Rh, Pt, Pd and $10 \mathrm{wt} . \%$ of $\mathrm{Ni}$ ) and calcination under air at $700^{\circ} \mathrm{C}$ for $4 \mathrm{~h}$.

The steam reforming of ethanol was carried out in a fixed bed reactor $(\mathrm{L}=550 \mathrm{~mm}$; $\varnothing \mathrm{int}=12.5$ $\mathrm{mm})$. The catalyst $(0.25 \mathrm{~g})$ mixed with carborundum $(2.75 \mathrm{~g})$ was pretreated under flowing $\mathrm{H}_{2}$ for $15 \mathrm{~h}$ at $675^{\circ} \mathrm{C}$. Then the reactor was purged under flowing $\mathrm{N}_{2}$ at the same temperature. After suppressing the gas flowing, ethanol and water were introduced in the reactor (molar ratio water/ethanol $=4,0.23 \mathrm{~mL} \mathrm{~min}^{-1}$ of liquid flowrate) with a HPLC pump. No carrier gas was added. The reaction was performed at $675^{\circ} \mathrm{C}$ and a pressure of 2 Bar. The experimental conditions, especially the weight hourly space velocity (WHSV $=19.5 \mathrm{~h}^{-1}$ ), determined by dividing the ethanol flowrate (in $\mathrm{g}$ per h) by the mass of catalyst (in $\mathrm{g}$ ), and the temperature were chosen in order to obtain less than $100 \%$ of ethanol conversion at the beginning of the reaction and to evidence the deactivation of the catalyst as a function of time, coke formation being favored at this temperature. In these experimental conditions, the yields in gaseous products are the $3.78 \mathrm{~mol} / \mathrm{mol}_{\text {ethanol }}$ for $\mathrm{H}_{2}$, $0.54 \mathrm{~mol} / \mathrm{mol}_{\text {ethanol }}$ for $\mathrm{CO}, 0.71 \mathrm{~mol} / \mathrm{mol}_{\text {ethanol }}$ for $\mathrm{CO}_{2}$ and $0.1 \mathrm{~mol} / \mathrm{mol}_{\text {ethanol }}$ for $\mathrm{CH}_{4}$. The ethanol chosen for the reaction is either pure ethanol or modified by one selected impurity (ethyl acetate, isobutanol, acetic acid ...) or raw bioethanol. The catalytic performances were examined taking into account the ethanol conversion and the hydrogen yield after $8 \mathrm{~h}$ of time-on-stream. 


\section{RESULTS AND DISCUSSION}

\subsection{Effect of impurities present in raw bioethanol on catalyst performances}

The main impurities present in raw bioethanol obtained from sugar beet are higher alcohols accounting for $87 \%$ of the impurities, the most important being propan-1-ol (27\%) and methyl-3 butan-1-ol (27\%), and also esters, aldehydes, acetic acid and nitrogen-containing bases (16).

In order to study the impact of each type of impurity on the ethanol steam reforming, "model" raw ethanol feeds were prepared by addition of $1 \mathrm{~mol} \%$ of one impurity in ethanol. Three series of impurities have been studied, namely (i) molecules with four carbon atoms and different functions (butanal, diethylether, butanol, ethylacetate) (ii) molecules with acidic and basic properties (acetic acid and diethylamine) and (iii) linear or branched alcohols (methanol, propan-1-ol, butan-1-ol, pentan-1-ol, isopropanol, 2-methylpropan-1-ol, 3-methylbutan-1-ol). The catalyst performances (hydrogen yield and ethanol conversion) were determined after $8 \mathrm{~h}$ of time-on-stream. In the absence or in the presence of impurities, the initial ethanol conversion was always high (98-99\%), but depending on the experimental conditions, the ethanol conversion decreased as a function of time, due to the deactivation of the catalyst, thus leading to a decrease in the hydrogen yield.

The results obtained in the presence of the acidic and basic impurities, and in the presence of pure ethanol as a reference, are summarized in Fig. 1.

Fig. 1 shows that the presence of diethylamine favors the ethanol conversion, and slightly increases the hydrogen yield. This promoting effect of diethylamine may be explained by a competition of this basic molecule with the alcohol molecules for the acidic sites, in accordance with (17), thus inhibiting the dehydration of ethanol on these sites. The promoting effect of diethylamine on ethanol conversion may also be explained by a modification of the metal electronic properties resulting from an electron transfer of the free nitrogen doublet toward the metal phase $(18,19)$. 
A lower ethanol conversion is observed in the presence of acetic acid compared to the conversion obtained without impurity. As a result, the hydrogen yield is decreased. It has been shown in the literature that acetic acid may either promote olefin formation by increasing the acidity of the support surface or inhibit it while favoring the esterification of the alcohol by acetic acid, depending on the structure of the alcohol used (17). In the present study, neither ester nor acetone was observed. This result confirms that the presence of an acid such as acetic acid may favor the production of ethylene by dehydration reaction thus favoring the catalyst deactivation by coke deposition. It is also known that acetic acid forms acetate species at low temperature on clean noble metal surfaces and that acetate species decompose to yield $\mathrm{H}_{2}, \mathrm{CO}_{2}$ and adsorbed carbon on the surface (20,21). Then, the deactivation of the catalyst observed in the presence of acetic acid may be explained by the formation of coke, favored in the presence of this acidic molecule.

The results obtained in the presence of various impurities (aldehyde, ether, higher alcohol and ester) with the same amount of carbon atoms, i.e. butan-1-al, diethylether, butan-1-ol and ethyl acetate are summarized in Fig.2.

In presence of butanal, similarly to what was observed with diethylamine, the ethanol conversion is increased compared to the reference test (without impurity). The hydrogen yield is also as similar to that obtained with diethylamine. Conversely, the presence of the other impurities, i.e. the ester, ether, C4 alcohol, strongly affects the ethanol conversion thus decreasing the hydrogen yield. The poisoning effect of these impurities can be classified in this increasing order: butanol< diethylether $<$ ethyl acetate. This poisoning effect may be explained by an enhanced production of coke in the presence of these impurities. In the case of diethylether, ethylene, which is coke precursor, may be produced by the dehydration of this impurity on the acidic sites of the support, as described by Knözinger et al. (22). The deactivation observed in the presence of butanol may be linked to the production of butene by butanol dehydration. The deactivation by the ester may be due to the hydrolysis of ethylacetate on the acidic sites of the support, yielding ethanol and acetic acid (23), and then to the presence of acetic acid. However, as the deactivation observed is much more 
important than that observed in the presence of acetic acid, the deactivation may be explained also by a competitive adsorption, since it has been reported in the literature that ethylacetate is more strongly adsorbed on alumina than ethanol (21) and that this stronger adsorption leads to an inhibition of ethanol oxidation.

The results obtained in the presence of various alcohols, linear or branched, are reported in Fig.3a and Fig.3b, respectively.

In the presence of methanol (Fig.3a), the ethanol conversion is not modified but the hydrogen yield is slightly increased, compared to the reference test. Then, it can be inferred that this alcohol has no effect on ethanol steam reforming, probably because methanol is easily converted by steam reforming, thus producing also hydrogen. As far as the higher alcohols are concerned, one can see that the ethanol conversion and the hydrogen yield decrease when the amount of carbon atoms in the molecule is increased. This effect is more pronounced in the presence of branched alcohols compared to the linear ones. Once again, the deactivation of the catalyst in the presence of this type of impurity may be explained in terms of coke deposition: alcohols are dehydrated to the corresponding olefin, which is then polymerized to yield coke, the coke extent increasing with the amount of carbon atoms in the olefin. The more important deactivating effect of the branched alcohols may be explained by the formation of more stable carbocations thus facilitating the olefin production.

In conclusion, except methanol, diethylamine and butanal, all the impurities identified in raw bioethanol lead to the deactivation of the $\mathrm{Rh} / \mathrm{MgAl}_{2} \mathrm{O}_{4}$ catalyst, mainly by coke deposition. The coke deposition has been confirmed by performing temperature programmed experiments on the deactivated catalyst. These experiments allowed us to quantify the amount of coke deposited onto the catalyst surface. Compared to the experiment performed in the presence of pure ethanol, the presence of impurities increased the amount of coke by a factor 2 to 3 . Consequently, the catalyst formulation must be improved, by modifying the support and then metallic phase, in order to find a stable catalyst able to convert raw bioethanol by steam reforming. 


\subsection{Modification of the support}

Rare earth element added to a support such as alumina are known to improve the catalytic performance in steam reforming and the stability of the catalysts, by decreasing its acidity, thus disfavoring the olefin formation, and by increasing the basicity, necessary to activate water. In order to improve the catalyst stability in the presence of raw bioethanol, various rare earth $(\mathrm{RE})$ elements, namely $\mathrm{RE}=\mathrm{Sc}$, Y, La, Er and Gd, were added to the alumina support instead of $\mathrm{Mg}$ and the catalytic properties of the $\mathrm{Rh} / \mathrm{RE}-\mathrm{Al}_{2} \mathrm{O}_{3}$ catalysts were compared to those of a $\mathrm{Rh} / \mathrm{Al}_{2} \mathrm{O}_{3}$ catalyst. The characterization of this catalyst series has been described in detail by Can et al. (24).

The surface acidity was determined by infra-red (IR) spectroscopy of adsorbed pyridine. It was demonstrated that the concentration of strong and medium Lewis acid sites decreases as a function of the support as the following: $\mathrm{Al}_{2} \mathrm{O}_{3}>\mathrm{La}-\mathrm{Al}_{2} \mathrm{O}_{3}>\mathrm{Er}-\mathrm{Al}_{2} \mathrm{O}_{3}>$ Gd- $\mathrm{Al}_{2} \mathrm{O}_{3}>\mathrm{Sc}-\mathrm{Al}_{2} \mathrm{O}_{3}>\mathrm{Y}-\mathrm{Al}_{2} \mathrm{O}_{3}$. It is known that surface acidic sites favors the ethanol dehydration reaction leading to ethylene, which is coke precursor. Consequently, the lower the acidity, the higher stability of the catalysts. On the other hand, basic sites of the support favor the dehydrogenation route yielding acetaldehyde. The basicity of the supports was determined by carbon dioxide thermodesorption followed by IR spectroscopy. These results allowed us to establish a ranking of the support basicity as follows: $\mathrm{La}-\mathrm{Al}_{2} \mathrm{O}_{3}>\mathrm{Y}-\mathrm{Al}_{2} \mathrm{O}_{3}>$ Sc$\mathrm{Al}_{2} \mathrm{O}_{3}>\mathrm{Er}-\mathrm{Al}_{2} \mathrm{O}_{3}>\mathrm{Gd}-\mathrm{Al}_{2} \mathrm{O}_{3}>\mathrm{Al}_{2} \mathrm{O}_{3}$.

The catalytic performances of the $\mathrm{Rh} /(\mathrm{RE})-\mathrm{Al}_{2} \mathrm{O}_{3}$ catalysts for ethanol steam reforming were determined in the presence of pure ethanol, i.e. without impurities. Results, reported in Fig.4, show that the addition of a rare-earth element onto alumina allows one to increase the hydrogen yield. Moreover, in all cases, the conversion is near $100 \%$ and the hydrogen yield is much higher than that obtained with the reference $\mathrm{Rh} / \mathrm{MgAl}_{2} \mathrm{O}_{4}$ catalyst.

As far as the hydrogen production is concerned, the following ranking can be suggested: $\mathrm{Y}-\mathrm{Al}_{2} \mathrm{O}_{3}>\mathrm{La}-$ $\mathrm{Al}_{2} \mathrm{O}_{3}>\mathrm{Sc}-\mathrm{Al}_{2} \mathrm{O}_{3}>$ Gd- $\mathrm{Al}_{2} \mathrm{O}_{3}>\mathrm{Er}-\mathrm{Al}_{2} \mathrm{O}_{3}=\mathrm{Al}_{2} \mathrm{O}_{3}$. The highest hydrogen yield is obtained with the 
$\mathrm{Rh}$ catalyst supported on $\mathrm{Y}-\mathrm{Al}_{2} \mathrm{O}_{3}$, which is the less acidic support and one of the most basic. Consequently, this support has been chosen for the following in order to improve the catalytic phase.

\subsection{Modification of the metallic phase}

In order to continue to improve the catalytic performance in terms of catalyst stability and hydrogen yield, the metallic phase was modified by adding a second metal, namely: Ni, Pt or Pd. As it was shown before that in the presence of the $\mathrm{Rh} / \mathrm{Y}-\mathrm{Al}_{2} \mathrm{O}_{3}$ catalyst, the conversion after $8 \mathrm{~h}$ of time-onstream is slightly lower than $100 \%$ in the presence of pure ethanol, we have chosen to compare the catalytic performances of the $\mathrm{Rh}-\mathrm{Ni} / \mathrm{Y}-\mathrm{Al}_{2} \mathrm{O}_{3}, \mathrm{Rh}-\mathrm{Pt} / \mathrm{Y}-\mathrm{Al}_{2} \mathrm{O}_{3}, \mathrm{Rh}-\mathrm{Pd} / \mathrm{Y}-\mathrm{Al}_{2} \mathrm{O}_{3}$ for ethanol steam reforming, in the presence of methyl-2-propanol, which is one of the most deactivating impurity identified in raw bioethanol. Results are reported in Fig.5.

These results show that the presence of nickel or palladium allows one to increase the hydrogen yield, whereas platinum has no beneficial effect. Nevertheless, the promoting effect of $\mathrm{Ni}$ is more pronounced than that of palladium. The better performances of the Rh-Ni catalysts may be explained either by a better water-gas shift activity (eq.7) or by a better methane steam reforming activity (eq.8), both reactions leading to the formation of hydrogen according to:

$$
\begin{aligned}
& \mathrm{CO}+\mathrm{H}_{2} \mathrm{O} \leftrightarrow \mathrm{CO}_{2}+\mathrm{H}_{2} \\
& \mathrm{CH}_{4}+\mathrm{H}_{2} \mathrm{O} \rightarrow \mathrm{CO}+3 \mathrm{H}_{2}
\end{aligned}
$$

In Fig. 6 are reported the yield in carbon monoxide and in methane obtained after $8 \mathrm{~h}$ of time-onstream.

Fig.6 shows that the yield in $\mathrm{CO}$ is slightly increased in the presence of $\mathrm{Rh}-\mathrm{Pd}$ and $\mathrm{Rh}-\mathrm{Ni}$ catalysts compared to that obtained in the presence of $\mathrm{Rh}$ (from 0.7 to 0.79 and 0.75 respectively), but the methane yield is much more decreased (from 0.55 to 0.49 and 0.46 respectively). It can be inferred 
from these results that the presence of $\mathrm{Pd}$ or $\mathrm{Ni}$ decreases slightly the activity of the catalysts for the water-gas shift reaction but increases in a major extent the activity in methane steam reforming. As this reaction yields 3 molecules of hydrogen per molecule of methane converted, the highest hydrogen yield obtained with the Rh-Ni catalyst may be explained by its higher activity in methane steam reforming compared to the Rh catalysts.

\subsection{Stability of the optimized catalyst in the presence of raw bioethanol}

It has been shown that the reference catalyst, $\mathrm{Rh} / \mathrm{MgAl}_{2} \mathrm{O}_{4}$, is deactivated in the presence of a lot of impurities as identified in raw bioethanol. Then, the catalyst formulation was improved and a Rh-Ni/Y$\mathrm{Al}_{2} \mathrm{O}_{3}$ allowed us to increase the ethanol conversion and the hydrogen yield. These two catalysts were then tested in the raw bioethanol steam reforming. Fig. 7 reports the ethanol conversion as a function



This figure clearly shows that the optimized catalyst, $\mathrm{Rh}-\mathrm{Ni} / \mathrm{Y}-\mathrm{Al}_{2} \mathrm{O}_{3}$, is very stable, in spite of the severe reaction conditions chosen, since the conversion is only slightly decreased after $24 \mathrm{~h}$ of timeon-stream (97\% of conversion compared to $100 \%$ at the beginning of the reaction). After $24 \mathrm{~h}$ of timeon-stream, the hydrogen yield is very high $\left(3.49 \mathrm{~mol} / \mathrm{mol}_{\text {ethanol }}\right)$, slightly lower than the value at the thermodynamic equilibrium $\left(3.78 \mathrm{~mol} / \mathrm{mol}_{\text {ethanol }}\right)$. On the contrary, the reference catalyst, $\mathrm{Rh} / \mathrm{MgAl}_{2} \mathrm{O}_{4}$ is strongly deactivated, probably by coke deposition, in the same reaction conditions, especially during the first $2 \mathrm{~h}$ of reaction.

\section{CONCLUSIONS}

A reference catalyst, $\mathrm{Rh} / \mathrm{MgAl}_{2} \mathrm{O}_{4}$, was tested in the presence of various impurities as identified in raw bioethanol from sugar beet. Whereas the presence of diethylamine, butanal and methanol has no negative effect on the ethanol conversion after $8 \mathrm{~h}$ of reaction, the presence of the other impurities (esters, acids, higher alcohols, linear or branched) strongly deactivates the catalyst, probably by coke deposition. Consequently, the catalyst formulation was modified to improve the catalytic performances 
(activity and stability) in the presence of raw bioethanol. In order to disfavor the coke formation, the acidity of the support was decreased by addition of rare earth elements, the acidic sites being responsible for olefin formation at the origin of coke production. The metallic phase was also modified by adding a second metal favoring either the water gas shift or the methane steam reforming reaction. It was shown that the addition of nickel leads to a higher hydrogen yield, probably due to the higher methane steam reforming activity of the resulting catalyst. Thus, the optimized $\mathrm{Rh}-\mathrm{Ni} / \mathrm{Y}-\mathrm{Al}_{2} \mathrm{O}_{3}$ catalyst is very stable in the presence of raw bioethanol, allowing us to obtain a high ethanol conversion under the severe experimental conditions chosen, with a high hydrogen yield.

\section{REFERENCES}

1. E.Y. Garcia and M. A. Laborde, Hydrogen production by the steam reforming of ethanol: Thermodynamic analysis, Int. J. of Hydrogen Energy 16 (1991) 307-312.

2. S. Cavallaro and S. Freni, Ethanol steam reforming in a molten carbonate fuel cell. A preliminary kinetic investigation, Int. J. Hydrogen Energy, 21 (1996), 465.

3. F. Aupretre, C. Descorme and D. Duprez, Bio-ethanol catalytic steam reforming over supported metal catalysts, Catal. Comm. 3 (2002) 263-267.

4. D.K. Liguras, D.I. Kondarides and X.E. Verykios, Production of hydrogen for fuel cells by steam reforming of ethanol over supported noble metal catalysts, Appl. Catal. B 43 (2003) 345-354.

5 F. Frusteri, S. Freni, L. Spadaro, V. Chiodo, G. Bonura, S. Donato and S. Cavallaro, $\mathrm{H}_{2}$ production for $\mathrm{MC}$ fuel cell by steam reforming of ethanol over $\mathrm{MgO}$ supported $\mathrm{Pd}, \mathrm{Rh}, \mathrm{Ni}$ and $\mathrm{Co}$ catalysts, Catal. Comm., 5 (2004) 611.

6 A.N. Fatsikostas and X.E. Verykios, Reaction network of steam reforming of ethanol over Nibased catalysts, J. Catal. 225 (2004) 439-452. 
7. J. Sun, X.-P. Qiu, F. Wu, W.-T. Zhu, H. from steam reforming of ethanol at low temperature over $\mathrm{Ni} / \mathrm{Y} 2 \mathrm{O} 3, \mathrm{Ni} / \mathrm{La} 2 \mathrm{O} 3$ and Ni/A12O3 catalysts for fuel-cell application, Int. J. of Hydrogen Energy, 30 (2005) 437-445.

8. F. Aupretre, C. Descorme, D. Duprez, D. Casanave and D. Uzio, Ethanol steam reforming over MgxNi1-xAl $2 \mathrm{O} 3$ spinel oxide-supported Rh catalysts, J. Catal., 233 (2005) 464-477.

9. N. Palmeri, S. Cavallaro, V. Chiodo, S. Freni, F. Frusteri, J.C.J. Bart, hydrogen production from ethanol on $\mathrm{Rh} / \mathrm{MgO}$ based catalysts. The influence of rhodium precursor on catalytic performance. Int. J. of Hydrogen Energy, 32 (2007) 3335-3342.

10. M.C. Sanchez-Sanchez, R.M. Navarro, J.L.G. Fierro, Ethanol steam reforming over Ni/M $\mathrm{M}_{\mathrm{x}} \mathrm{O}^{-}$ $\mathrm{Al}_{2} \mathrm{O}_{3}(\mathrm{M}=\mathrm{Ce}, \mathrm{La}, \mathrm{Zr}$ and $\mathrm{Mg})$ catalysts: Influence of support on the hydrogen production. Int. J. of Hydrogen Energy 32 (2007) 1462-1471.

11. L. P.R. Profeti, E.A. Ticianelli, E.M. Assaf, Production of hydrogen via steam reforming of biofuels on $\mathrm{Ni} / \mathrm{CeO} 2-\mathrm{A} 12 \mathrm{O} 3$ catalysts promoted by noble metals. Int. J. of Hydrogen Energy 34 (2009) 5049-5060.

12. Andréia Cristina Furtado, Christian Gonçalves Alonso, Mauricio Pereira Cantao, Nadia Regina Camargo Fernandes-Machado, Bimetallic catalysts performance during ethanol steam reforming: Influence of support materials, Int. J. of Hydrogen Energy 24 (2009) 7189-7196.

13. D. Duprez, A. Miloudi, G. Delahay and R. Maurel, Selective steam reforming of aromatic hydrocarbons. IV. Steam conversion and hydroconversion of selected monoalkyl- and dialkylbenzenes on Rh catalysts, J. Catal. 90 (1984) 292-303.

14. J.C. Vargas, S. Libs, A.-C. Roger and A. Kiennemann, Study of Ce-Zr-Co fluorite-type oxide as catalysts for hydrogen production by steam reforming of bioethanol, Catal. Today 107-108 (2005) 417-425.

15. A.J. Akande, R. O. Idem, A.K. Dalai, Synthesis, characterization and performance evaluation of $\mathrm{Ni} / \mathrm{Al} 2 \mathrm{O} 3$ catalysts for reforming of crude ethanol for hydrogen production, Appl. Catal. A, 287 (2005) 159. 
16. A. Le Valant, A. Garron, N. Bion, F. Epron and D. Duprez, Hydrogen production from raw bioethanol over Rh/MgAl2O4 catalyst. Impact of impurities: Heavy alcohol, aldehyde, ester, acid and amine, Catal. Today 138 (2008) 169-174.

17. J.R. Jain and C.N. Pillai, Catalytic dehydration of alcohols over alumina. Mechanism of ether formation, J. Catal. 9 (1967) 322-330.

18. J.P. Boitiaux, J. Cosyns and E. Robert., Additive effects in the selective hydrogenation of unsaturated hydrocarbons on platinum and rhodium catalysts. I: Influence of nitrogen-containing compounds, Appl. Catal. 49 (1989) 219-234.

19. B. Nohair, C. Especel, G. Lafaye, P. Marécot, Lê Chiên Hoang, J. Barbier, Palladium supported catalysts for the selective hydrogenation of sunflower oil, J. Mol. Catal. A 229 (2005) 117-126.

20. Y. Li and M. Bowker, Acetate formation, stabilisation and surface explosion on Rh(111), Surface Science, 285 (1993) 219-226.

21. D. Wang, D. Montané, E. Chornet, Catalytic steam reforming of biomass-derived oxygenates: Acetic acid and hydroxyacetaldehyde, Appl. Catal. A, 143 (1996) 245-270.

22. H. Knözinger and R. Köhne, The dehydration of alcohols over alumina. I. The reaction scheme, J. Catal. 5 (1966) 264-270.

23. J.E. Sawyer and M.A. Abraham, Reaction pathways during the oxidation of ethyl acetate on a platinum/alumina catalyst, Industrial and Engineering Chemistry Research, 33 (1994) 2084-2089. 24. F. Can, A. Le Valant, N. Bion, F. Epron, D. Duprez, New active and selective Rh-REOx-A12O3 catalysts for ethanol steam reforming, J. Phys. Chem. C 112 (2008) 14145-14153. 


\section{Figure Captions}

Fig.1. Hydrogen yield and ethanol conversion with or without impurities (diethylamine or acetic acid) determined after $8 \mathrm{~h}$ of time-on-stream in the presence of $\mathrm{Rh} / \mathrm{MgAl}_{2} \mathrm{O}_{4}$.

Fig.2. Hydrogen yield and ethanol conversion with or without impurities (butan-1-al, diethylether, butan-1-ol and ethyl acetate) determined after $8 \mathrm{~h}$ of time-on-stream in the presence of $\mathrm{Rh} / \mathrm{MgAl}_{2} \mathrm{O}_{4}$.

Fig.3 : Hydrogen yield and ethanol conversion with or without impurities (a) methanol, propan-1-ol, butan-1-ol, pentan-1-ol, (b) isopropanol, 2-methylpropan-1-ol, 3-methylbutan-1-ol, determined after $8 \mathrm{~h}$ of time-on-stream in the presence of $\mathrm{Rh} / \mathrm{MgAl}_{2} \mathrm{O}_{4}$.

Fig.4 : Hydrogen yield and ethanol conversion without impurities determined after $8 \mathrm{~h}$ of time-onstream in the presence of various catalysts.

Fig 5 : Hydrogen yield and ethanol conversion in the presence of 2-methyl-propan-1ol as impurity, determined after $8 \mathrm{~h}$ of time-on-stream in the presence of various metal phase $(\mathrm{Rh}, \mathrm{Rh}-\mathrm{Ni}, \mathrm{Rh}-\mathrm{Pt}$, $\mathrm{Rh}-\mathrm{Pd}$ ) supported on the $\mathrm{Y}-\mathrm{Al}_{2} \mathrm{O}_{3}$ support.

Fig. 6: Carbon monoxide and methane yields in the presence of 2-methyl-propan-1ol as impurity, determined after $8 \mathrm{~h}$ of time-on-stream in the presence of various metal phase $(\mathrm{Rh}, \mathrm{Rh}-\mathrm{Ni}, \mathrm{Rh}-\mathrm{Pt}$, $\mathrm{Rh}-\mathrm{Pd}$ ) supported on the $\mathrm{Y}-\mathrm{Al}_{2} \mathrm{O}_{3}$ support.

Fig 7: Ethanol conversion as a function of time-on-stream during the steam reforming of raw bioethanol in the presence of the $\mathrm{Rh} / \mathrm{MgAl}_{2} \mathrm{O}_{4}$ and $\mathrm{Rh}-\mathrm{Ni} / \mathrm{Y}-\mathrm{Al}_{2} \mathrm{O}_{3}$ catalysts. 


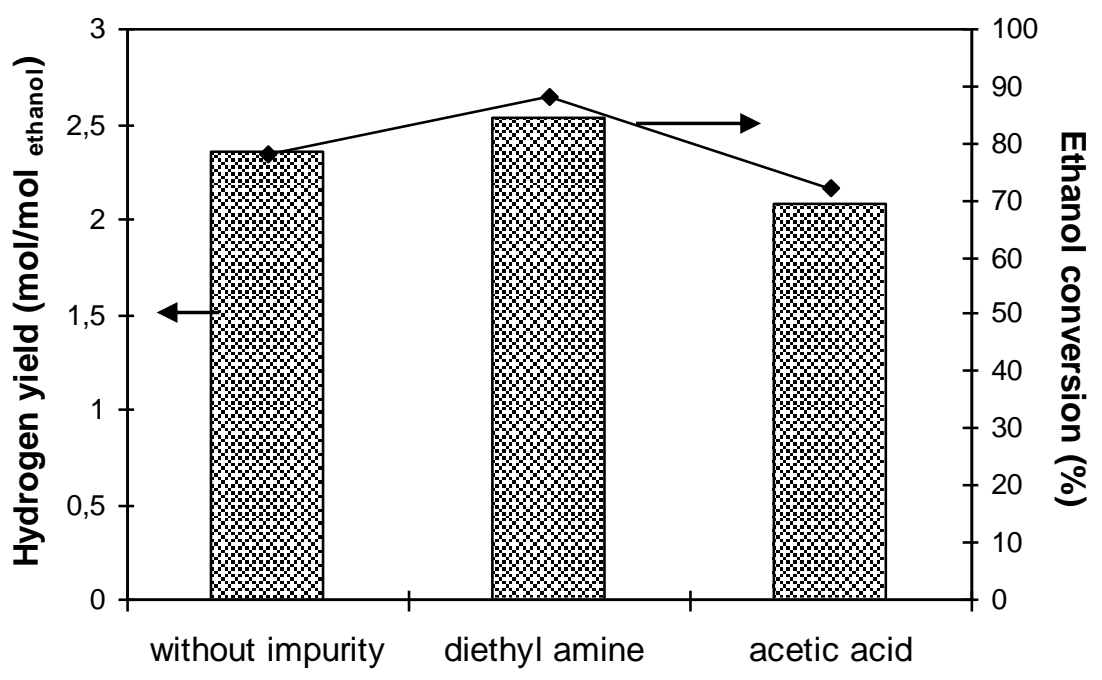

Fig.1. 


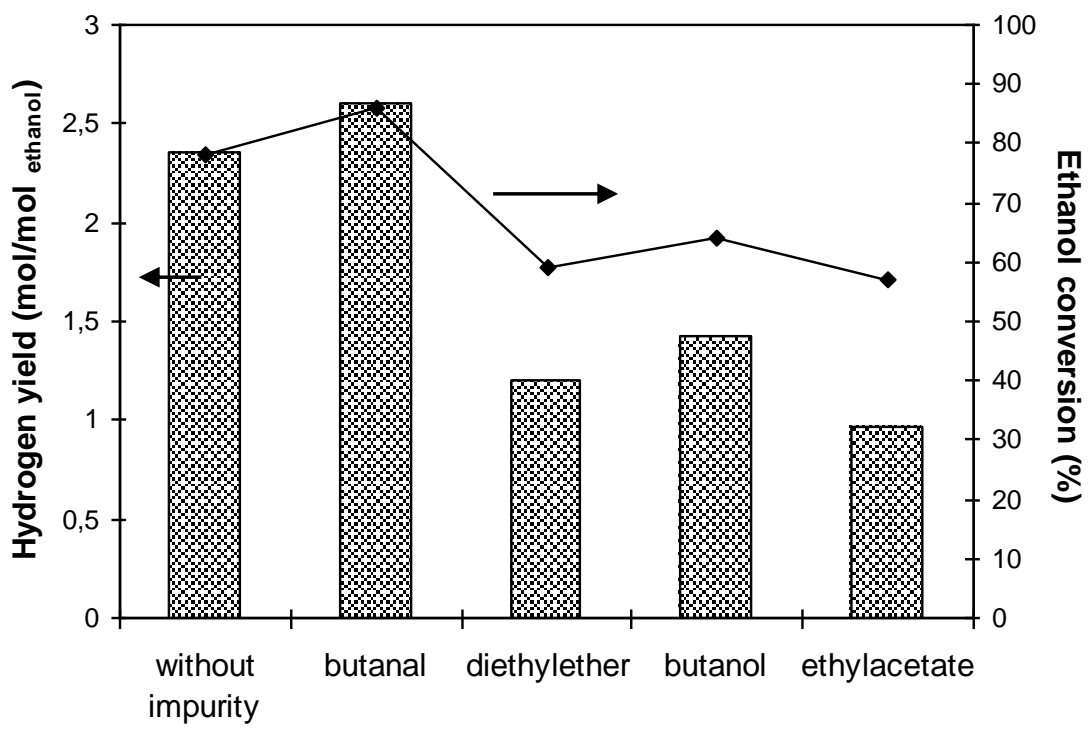

Fig.2. 



Fig.3 




Fig.4 


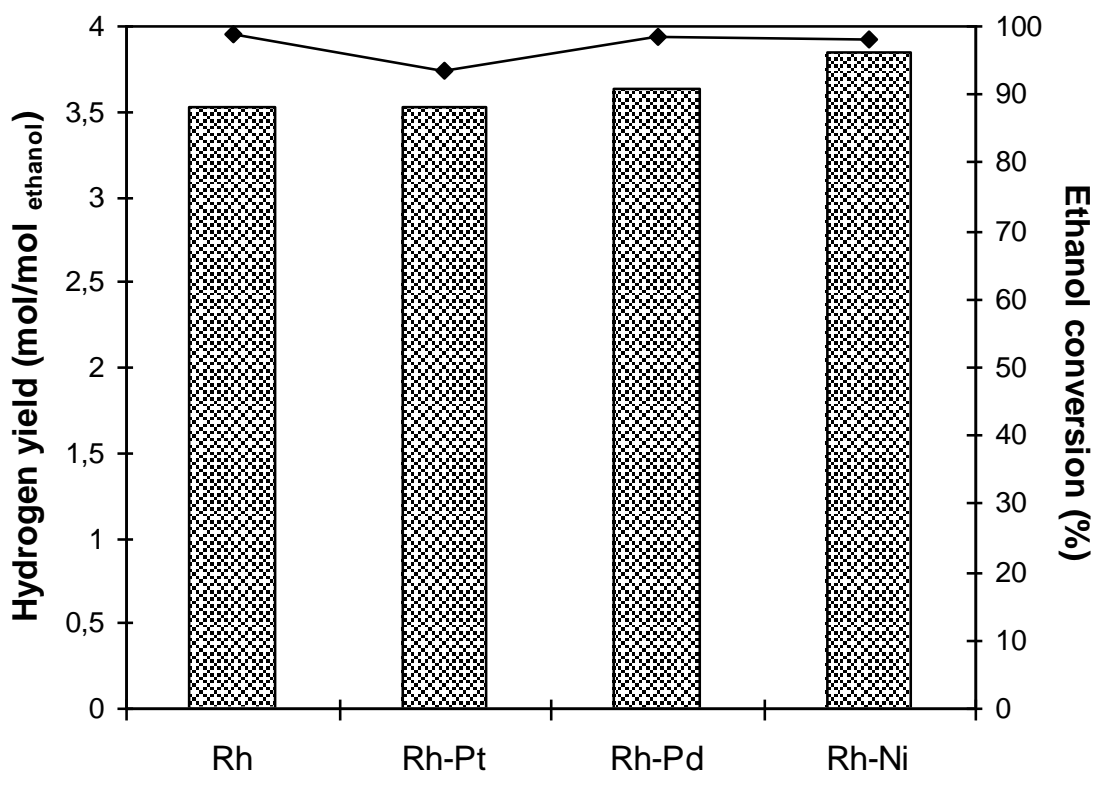

Fig 5 


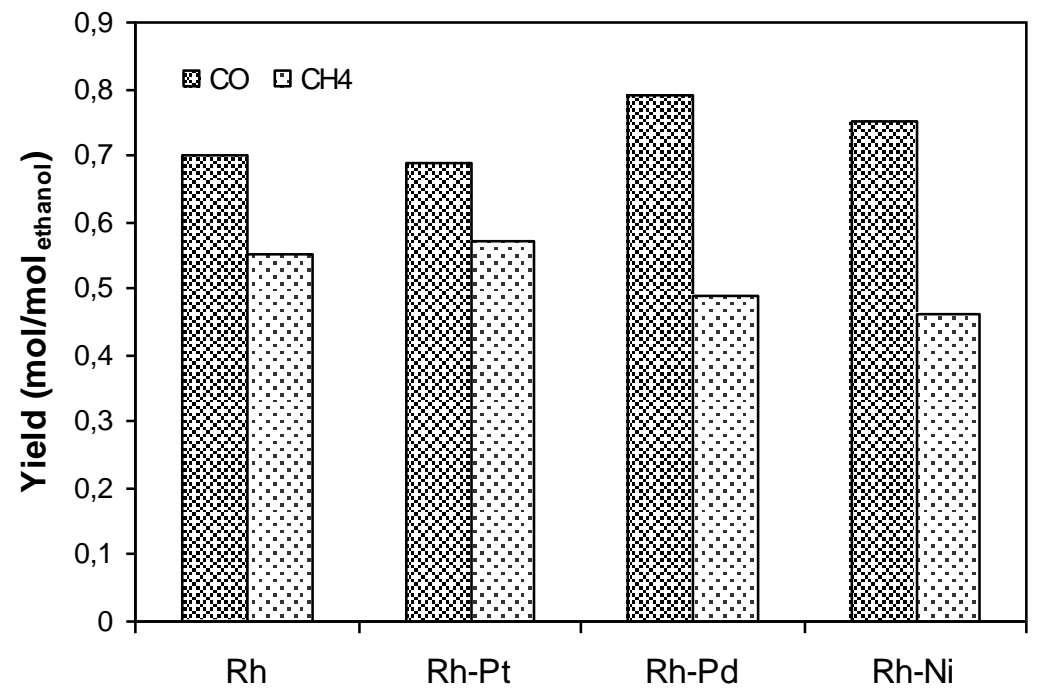

Fig. 6 


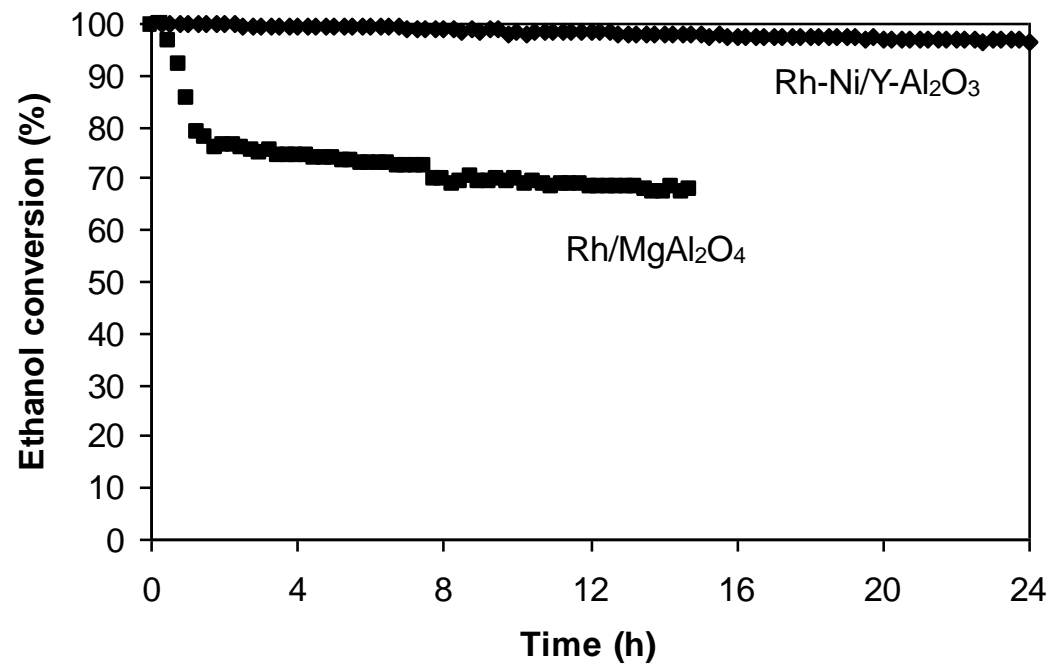

Fig 7: 